\title{
Siting conflict and peace in post-tsunami Sri Lanka and Aceh, Indonesia
}

\author{
JENNIFER HYNDMAN
}

\begin{abstract}
The article aims to analyse two policy narratives that were politicised in the context of post-tsunami response in Eastern Sri Lanka and Aceh, Indonesia. These areas had been affected by war for several decades before the tsunami hit. The first narrative of public safety saw government imposition of post-tsunami buffer zones, ostensibly as measures to protect those affected, but they also incited tensions in both locations. The second relates to post-tsunami aid distribution. Developing policies and implementing bodies for tsunami aid has proven highly contentious, but uniquely so in each location. Whereas the tsunami in Sri Lanka has been followed by renewed fighting and the end of the 2002 Ceasefire Agreement, the province of Aceh enjoys the fruits of the 2005 peace agreement that has created greater autonomy from central government and greater access to resources than ever before. Each conflict has historically and geopolitically distinct antecedents, resulting in very different post-disaster policy contexts and political challenges on the ground.
\end{abstract}

Keywords: Aceh, aid, conflict, Sri Lanka, tsunami

The tsunami of 26 December 2004 led to extraordinary devastation and destruction for peoples of the Indian Ocean Basin region. The earthquake that spawned it killed an estimated 167,000 people in Aceh, the closest land mass to the epicentre on the Indonesian island of Sumatra. In Sri Lanka, more than 36,000 people died, and another 800,000 were displaced from their homes. Overseas aid was unprecedented. In total, more than USD 13 billion was pledged, with more than USD 5 billion coming from private individuals and companies. Yet, in comparison the destruction and loss of life from the immense earthquake that struck Pakistan soon after hardly registered among private donors of the global North less than one year later (GrundyWarr \& Sidaway 2006).

Several of the states affected by the 2004 tsunami were host to long-term conflicts before the disaster, including Aceh and Sri Lanka, but also Burma (officially known as Myanmar), Somalia, and India. This coincidence of humanitarian crises - conflict on the one hand, and the tsunami on the other - raises important questions: What effect did the 2004 tsunami in the Indian Ocean Basin have on the extant contexts of conflict and peace in Aceh and Sri Lanka? What policy narratives were mobilised in the aftermath of the tsunami in each location? Did these tsunami-related policies intersect with the extant conflicts in both environments? This article aims to provide some preliminary responses to these questions.

Policy matters; there is no such thing as a 'natural' disaster (Smith 2006). A widely-held view within disaster management is that human decisions and actions shape the outcome of particular emergencies. For example, in 2008, Burma (or Myanmar in official parlance) was drastically affected by Cyclone Nargis, which killed 130,000 people and displaced over two million more along the Irrawaddy Delta. This violent storm and the waves it generated became a fullblown humanitarian disaster because of government policy. Virtually no international aid organisations or staff were allowed into the area to assist those affected until almost one month after the cyclone hit. The idea of a policy-induced disaster is pertinent to all humanitarian crises, whether it is related to conflict, tsunamis, cyclones, earthquakes, or other calamities.

Adding to existing literature on the intersection of 'manmade' versus 'natural' disasters (Wisner et al. 2004; Kelman \& Gaillard 2007), this article juxtaposes geographies of conflict, devastation, and response in Sri Lanka and Aceh, Indonesia, two places acutely affected by the 2004 tsunami. A number of geographers (Korf 2005; Lawson 2005; Marston 2005; Olds et al. 2005; Stokke 2005; Kleinfeld 2007; Le Billon \& Waizenegger 2007; Gaillard et al. 2008) and other social scientists (e.g. Jeganathan 2005; Kennedy et al. 2008) have taken up different elements of the question probing the relation of the tsunami to the conflicts that preceded it.

This article seeks to juxtapose the cases of Sri Lanka and Aceh in the context of post-tsunami aid and reconstruction. Methodologically, however, the work on which it is based is not strictly comparative research. The contexts of Sri Lanka and Aceh, Indonesia are simply too distinct to forge such an approach. The fieldwork for this article was conducted in both countries after the tsunami. Interviews with tsunamiand conflict-affected people in Sri Lanka took place in February 2005 and 2006. Interviews were also conducted with UN personnel and the staff of international nongovernmental organisations (INGOs). In Banda Aceh, I held 27 interviews with UN personnel, government representatives, and INGOs in June 2007, as well as three individual interviews and one focus group with former combatants at that time. ${ }^{1}$ In 2008 , a further 50 interviews were completed with a cross-section of the same groups by research assistant Arne Waizenegger. This paper highlights issues and policies common to both contexts, but also examines responses at a more generalised level compared to a single case study. 
Perhaps the most important caveat framing this research is that geographically diverse processes produced the particular patterns and examples provided below. As Matthew Sparke (2005, xiv) reminds geographers, 'any assumption about geography either as a result of or as a basis or container of spatial relations for other social relations always risks fetishising a particular spatial arrangement and ignoring ongoing processes of spatial production, negotiation, and contestation'. To overstate any geographical similarities is to ignore the multi-scalar actors and relationships that generate distinctive histories of struggle as well as contemporary policies and responses to the devastation of the tsunami of 2004. Contextualising the spaces of disaster, then, is an important departure point.

The people of Aceh have long fought for autonomy against colonial rulers as well as the centralised Government of Indonesia. In Sri Lanka, the political aspirations of a separate breakaway Tamil state by the Liberation Tigers of Tamil Eelam (LTTE) is a post-independence war, stemming from the anti-Tamil pogroms of 1983 in Colombo. Calls for a separate state in Sri Lanka can be traced to the early 1970s, when constitutional reforms alienated Tamils in what was formerly Ceylon. Both conflicts were in their third consecutive decade when the tsunami hit.

Today, several years after the 2004 tsunami event, political and economic conditions in the two affected areas are both dramatically different and starkly similar. In Aceh, the Indonesian Government signed a peace agreement with the Free Aceh Movement (Gerakan Aceh Merdeka or GAM) in August 2005, just eight months after the tsunami; it was still operational at the end of 2008. In Sri Lanka, political developments since the tsunami have intensified the country's prolonged political crisis (Uyangoda 2005), leading to the abrogation of the 2002 Ceasefire Agreement in 2008 by the Sri Lankan Government in the wake of rebel attacks. The number of civilian deaths since the tsunami continues to climb in Sri Lanka, while Aceh enjoys a precarious but continuous period of calm.

Despite this crude political contrast of peace and war, both places continue to host political tensions and resentment in the wake of tsunami reconstruction. The landscapes of conflict and displacement that preceded the tsunami have not been and cannot be erased. Rather, a variegated, politicised layer of aid overlays the earlier disparities, histories, and geographies of displacement. In Sri Lanka:

[s]truggles over inter-ethnic justice, neo-liberalism, economic distribution, the disempowerment of women, caste bigotry and such have shaped the [Sri] Lankan political landscape in significant ways over the last decades...even the tsunami cannot wipe out the imprint of these fault lines. (Nesiah et al. 2005)

As Michael Renner (2006) notes in the case of Aceh, the ulamas (Islamic theologians) have blamed women for the tsunami, calling them 'female sinners' whose dress, for example, was not morally appropriate prior to the disaster. Shari'a law pre-dated the tsunami but the Shari'a police did not emerge until afterwards. A feminist analysis of these political transformations remains to be done. Distinct societal cleavages, political tensions, and economic disparities between Aceh and Sri Lanka pre-date the tsunami, so any juxtaposition must avoid direct comparison that might eclipse the nuanced differences and dynamics that have historically and geographically constituted each place (Action Aid 2006).

\section{Political geographies of displacement: pre- tsunami}

The devastation of the tsunami overlays longstanding geopolitical tensions, struggles for resources, and political geographies of displacement (Hyndman \& de Alwis 2004; Nah \& Bunnell 2005). In what follows I briefly sketch the political backdrop to conflict in both Aceh and Sri Lanka, setting the stage for the 'tsunami politics' that ensued after the fateful waves of 26 December 2004 hit Aceh and Sri Lanka.

\section{Indonesia}

Sentiments towards sovereignty and Islam in Aceh are more pronounced than in most other parts of Indonesia. When Dutch forces recaptured Indonesia in 1946, after Japan's defeat in World War II, Aceh remained the only free region of the archipelago (Waizenegger 2007). Both Acehnese people and politicians broadly supported the creation of the Indonesian Republic in principle, in large part because they believed it would be an Islamic state and Aceh would be granted special provincial status (Aspinall 2007). The creation of a secular and centralised Federal Republic of Indonesia in 1949 betrayed Aceh's loyalty and support, sowing seeds of rebellion.

In response to this dissidence, Indonesian President Sukarno granted Aceh separate provincial status in 1959, and gave it the status of a 'special region' (Daerah Istimewa) in 1961 to pacify the Acehnese. However, Sukarno's political nemesis, President Suharto, stoked discontent during his rule, beginning in the mid-1960s. Feelings of exploitation soared among the Acehnese in 1971 when huge oil and liquid natural gas deposits were discovered near Lhokseumawe and Lhoksukon in North Aceh. Exploration was followed by the construction of what was then a huge refinery in worldwide terms, financed as joint venture between the Indonesian state-owned Pertafina and ExxonMobil (Renner 2006).

Other companies seeking to run the refinery included Doral International, a conglomerate owned by the Acehnese businessman Teungku Hasan di Tiro (Waizenegger \& Hyndman in press). Di Tiro is a descendant of the last sultan of Aceh, and a direct descendant of Teuku Cik Di Tiro, a famous Acehnese national hero during the Aceh War of 1873-1903, so his defeat in the oil deal was seen as a renewed expression of the unjust Javanese economic exploitation and domination of the province. The confiscation of villagers' land without compensation by the Government of Indonesia and the deployment of as many 
as 5000 troops to protect ExxonMobil from the emerging rebel force also fuelled Acehnese nationalism (Renner 2006).

The Free Aceh Movement (GAM) has been fighting for Aceh's independence from Indonesia since 1976. After a number of attacks by GAM in 1989-1990 - a period of extensive human rights violations on both sides - the Indonesian military launched a massive counterinsurgency operation in Aceh Province which continued on and off into 2005 (Nah \& Bunnell 2005). Conflict, violence, and the sustained counter-insurgency had displaced more than 300,000 people since 1999 , well before the tsunami hit. In December 2002, a cessation of hostilities agreement was signed, drastically reducing the number of killings (Renner 2006). Yet, by May 2003, in response to renewed Acehnese calls for a share of resource revenues, the Government of Indonesia declared a state of emergency in Aceh (Hedman 2005), and the region was highly militarised by the Indonesian government which installed more than 40,000 additional troops to forcibly relocate insurgents.

In October 2004, Susilo Bambang Yudhoyono became President of Indonesia, with a pledge to seek peace in Aceh. Then, in December 2004, the tsunami hit Aceh. Just eight months later, after five rounds of talks, a peace agreement, or memorandum of understanding (MoU), was signed in August 2005, securing withdrawal of troops, the disarmament of rebels, more energy revenues for the Aceh region, and greater autonomy for local government in Aceh. As the wording of the peace agreement specifically states: 'The parties are deeply convinced that only the peaceful settlement of the conflict will enable the rebuilding of Aceh after the tsunami disaster on 26 December 2004 to progress and succeed.' The newly elected president put it this way: 'The tsunami produced an overwhelming moral, political, economic, social imperative to end the conflict... I was criticised by those who did not see any benefit from renewed talks with GAM. But I was more concerned about the judgment of history for missing this rare window of opportunity to resolve the conflict' (President Yudhoyono, opening speech, 'Building Permanent Peace in Aceh: One Year After The Helsinki Accord' conference held in Jakarta, 14 August 2006). The principles of peace outlined in 2005 were passed into law governing Aceh, in diluted form due to resistance by hardliners, in July 2006 (Renner 2006).

Glassman (2005) argues that the Indonesian state was partially to blame for the susceptibility of people to death and destruction in Aceh during the tsunami. Despite Aceh's natural wealth in resources, Javanese sub-imperialism and the US-backed rule of President Suharto led to Acehnese 'people leading marginal lives and surviving on marginal resources' (Glassman 2005, 166). This confluence of cold war geopolitics, in which the West provided considerable backing for the Indonesian military and Java-centric governance that ensured energy revenues flowed from Aceh to Jakarta, generated a skewed political economy in the region. Such political currents continued even in the wake of the tsunami when, as Glassman reports, GAM honoured the ceasefire while the Indonesian military continued attacks on GAM strongholds.

\section{Sri Lanka}

In Sri Lanka, a war characterised as one of violent competing nationalisms between the secessionist Liberation Tigers of Tamil Eelam (LTTE) and the Government of Sri Lanka's armed forces has been waged for more than 25 years (Jayawardena \& de Alwis 1996, ix-xxii). Contemporary Sri Lanka is an expression of a long history and geography of struggle well-documented by Sri Lankan scholars (Abeysekera \& Gunasinghe 1987; Jeganathan \& Ismail 1995; Tiruchelvam 1996). At the time of writing (2008), the death toll from the conflict exceeds 70,000, and internal displacement follows as a consequence of the dynamics of conflict. During the Ceasefire Agreement between the Government and the LTTE, signed in February 2002, deaths fell dramatically until 2006, when hostilities resumed despite the Agreement. In a moment of donor hope in 2003, a conference to finance the reconstruction of war-torn Sri Lanka met in Tokyo; USD 4.5 billion was pledged for the 'Regaining Sri Lanka' strategy, referred to as a 'cash for peace approach' (Jeyeraj 2005; Bastian 2007a).

After the 2004 tsunami in Sri Lanka, the World Bank assessed the cost of reconstruction and recovery at approximately USD 1.5 billion. How to allocate these funds emerged as one of the biggest hurdles between the government and the LTTE. A joint mechanism to distribute international aid to tsunami-affected areas was proposed at an international donor forum in May 2005 (Kleinfeld 2007). Called the Post-Tsunami Operational Management Structure, or P-TOMS, the joint mechanism was a memorandum of understanding (MoU) that set out terms for a working relationship between the Government of Sri Lanka and the LTTE. P-TOMS had representation not only from the Sri Lankan Government and the LTTE, but also from Muslim political parties. Muslim communities living along the devastated east coast were disproportionately hit by the tsunami, given their overrepresentation in that region.

Signed in June 2005, the P-TOMS MoU was also a firebrand for political acrimony, galvanising Sinhalese nationalist sentiment in opposition to it because of the legitimacy it potentially conferred on the militant Tamil nationalists, the LTTE. The Sinhala nationalist Janatha Vimukthi Peramuna (JVP) party, in a coalition with the sitting government, petitioned the Supreme Court in July 2005 on the grounds that P-TOMS violated the rights of Sri Lankan citizens and the territorial integrity of the state on the following grounds (Kleinfeld 2007, 179):

- The LTTE was a terrorist organisation and not a governmental entity that could participate in such an agreement.

- The committees described in P-TOMS were governmental in nature and could not legally do the work they were charged to do without constitutional changes.

- Donor funds were funds of the Republic and could not be controlled by an outside agency such as the World Bank (as was outlined in the MoU).

- Treatment of persons within the tsunami disaster zone (TDZ) discriminated against tsunami-affected persons outside the TDZ. 
If P-TOMS had succeeded, it might have served as a blueprint for the constitutional change required for peace beyond a ceasefire in Sri Lanka; however, it did not. The Supreme Court largely agreed with the plaintiff, and the MOU was never adopted. Then Prime Minister Mahinda Rajapakse ran for President later in 2005 on an anti-PTOMS platform and won by a slim margin (Bastian 2007b). With his presidency and its consolidated alliance with Sinhalese hardliners, such as the JVP, violence has increased notably in Sri Lanka.

By early 2008, the Government of Sri Lanka had ended the ceasefire agreement and the Nordic monitors of the Sri Lanka Monitoring Mission (SLMM) had left the country. Bus bombs and suicide attacks in public areas, such as those witnessed throughout much of the late 1990s, have resumed. Between December 2004 and June 2007, more than 6000 people were killed (Kleinfeld 2007).

\section{Political geographies of displacement: post- tsunami buffer zone policies}

The tsunami generally worsened the humanitarian, social, and economic situation of people living in the province of Aceh and in Sri Lanka. The regions most affected - Western Aceh on the northern part of Sumatra island and the eastern coast of Sri Lanka ${ }^{2}$ - both have long histories of exclusion, poverty and conflict. Yet, the infusion of aid and the patterns it took created very different dynamics in each location. In both Sri Lanka and Aceh, money to rebuild houses was plentiful, but coordinating housing reconstruction and securing the land on which to build them were more elusive (Centre for Policy Alternatives 2005; Renner 2006). In both countries 'buffer zone' policies that initially prohibited rebuilding homes near the sea generated another wave of displacement, politicising humanitarian aid (Action Aid 2006). In the following section, I discuss a geography of displacement engendered by this policy. The buffer zone policy displaced yet again those who had already lost their homes through the dislocation of conflict and then the tsunami. In the case of Sri Lanka, this fuelled resentment among minority ethnic groups, namely Muslims and Tamils. Some Sri Lankan commentators have argued that the policy was politicised land grabbing on the part of a precarious government in one of the most densely populated countries in the world. ${ }^{3}$

Aceh, in contrast, experienced a different kind of politicisation in relation to the buffer zones; there, however, much more resentment based on unequal treatment of 'tsunami-affected' versus 'war-affected' people emerged in the form of protest. Below, I will address each of these contexts in turn.

\section{Fostering conflict, buffering blame in Sri Lanka}

When the buffer zone made its entrance after the waves had left behind the destruction [in January 2005], it was known by another name, less popular - set back zone. It most certainly has lived up to that title. (Perera 2005, 16)
The 'set back' or buffer zones declared by the Government of Sri Lanka represented a state-sponsored dislocation for many people along the east coast who had already been affected by the dual disasters of war and huge waves. Before the tsunami, during periods of intense conflict many Muslim and Tamil communities had found sanctuary on these unoccupied shores, which were narrow strips of land between the sea and the more inland lagoons, called littoral, or eluvankaral in Tamil). The hinterland, or paduvaankaral, farther inland from the lagoons is occupied largely by Sinhalese, the majority ethnic group, who were resettled from other parts of the country through government colonisation schemes during the nationalist periods of the 1950s and 1970s (Jeyeraj 2005).

From the time when the Sri Lankan Government announced the buffer zones, or no-build areas, cries of ethnic discrimination could be heard. Muslim communities were over-represented as a proportion of the general population in the hardest hit parts of eastern Ampara District and therefore over-represented in terms of the death and destruction wreaked in that area. So when the government announced a $200 \mathrm{~m}$ no-build zone along the east coast in contrast to a narrower $100 \mathrm{~m}$ buffer zone along the south coast, where homes of the Sinhala majority are most numerous, Tamil and Muslim groups called the buffer zones unfair and a sign of ethnic prejudice (de Alwis 2005). The zones served to reproduce extant patterns of discrimination against minority Tamils and Muslims in the wake of the tsunami and fuelled mistrust (Hyndman 2007).

In both areas, the high population density and scarcity of land also made the setbacks highly contentious. The President's office announced that the government would identify lands closest to the affected villages and build a house for every affected house owner who lived within the $100 \mathrm{~m}$ buffer zone (Sambandan 2005). It was further announced that owners of homes that were located inside the zone 'will retain the ownership of his original land' and that the government 'will not in any way claim ownership to such property'; moreover, the owner would be 'entitled to appropriate the land [within the $100 \mathrm{~m}$ zone] as he wishes, except building on it'. In addition, the government was to extend patronage to planting coconut or any other suitable crop on the land (Sambandan 2005). Land within the buffer zone could still be used for business purposes - a particularly important resource for tourist operators in Sinhala-dominated beach areas of southern Sri Lanka (MONLAR \& ANRHR 2005). Also, hotels were rebuilt less than $10 \mathrm{~m}$ from the high tide water mark. So, while Sri Lankan citizens could no longer reside along the south coast, tourists could.

The terms of rebuilding and compensation were also contentious. Owners of homes and squatters alike could have houses rebuilt with aid either from the government or from an approved non-governmental organisation, but tenants renting from owners received nothing except the right to rent again if and when owners rebuilt (Centre for Policy Alternatives 2005). The logic, or lack thereof, behind the decision showed early signs of strain.

As the Institute for Policy Studies (2005) in Colombo stated, if public safety was the prevailing aim, the buffer zones should have been equivalent for all areas. The specific 
environmental, social and physical characteristics of coastlines in different parts of the country ostensibly require responses tailored to those geographies. Instead, Sri Lanka's World Bank representative, Peter Harrold, noted that buffer zones have been the single greatest barrier to progress in housing reconstruction for those who lost their homes in the tsunami (cited in Dias 2006).

The lack of evidence used to rationalise the buffer zones is striking, a situation that politicised the policy and intensified ethno-national tensions. On 28 March 2005, an earthquake of similar magnitude and near the epicentre of the 2004 tsunami shook much of Sri Lanka. President Chandrika Kumaratunga stated that the mere occurrence of the earthquake, which did not create a tsunami, was a logical rationale for the buffer zone: 'the people now should realise that the government, bearing in mind all allegation leveled against it, has acted prudently with a vision and in a responsible manner' (Associated Press 2005). Meanwhile, an opposition MP and former minister, Ravi Karunanayake, retorted that in his riding of Crows Island 1500 National Housing Development Authority houses went underwater in the tsunami, despite the fact that they were built more than a $100 \mathrm{~m}$ from the shoreline, which was proof, he said, that the buffer zone would be ineffectual.

The buffer zones proved to be a political hot potato for President Chandrika Kumaratunga, whose term ended in November 2005, at which time her then Prime Minister, Mahinda Rajapakse, was elected President of Sri Lanka. Rajapakse quickly distanced himself from the Kumaratunga presidency, first by changing his predecessor's government tsunami response body from the Task Force to Rebuild the Nation (TAFREN) to the Reconstruction and Development Agency (RADA). Then, through RADA, he announced in February 2006 that the buffer zone 'set back standards' would be relaxed and that the setback standards of the Coastal Zone Management Plan of 1997 would be revived (The Sunday Times 2006).

While the Advisory Council of the Coast Conservation Department approved exemptions from the buffer zone policy even before Kumaratunga left office (Cassim 2005), Rajapakse appeared to have a scientific reason for invoking the Coastal Zone Management Plan. The plan had been implemented but not enforced by various Sri Lankan governments since the 1980s and was based on protecting the coast and its inhabitants through appropriate vegetation. The 1997 version allowed for setbacks between $35 \mathrm{~m}$ and 125 $\mathrm{m}$ from the permanent vegetation boundary, depending on coastal conditions. That the plan pre-dated the tsunami and appeared to the public to be based on environmental science depoliticised the buffer zone controversy.

\section{Aceh's blueprint and buffers}

In Aceh, the size of buffer zones announced by the government was substantially greater at the outset: 'Within a two-kilometre area from the shore, we will avoid building houses, offices, markets and shopping centres' (Mawardi Nurdea, head of Aceh's urban planning and housing authority in February 2005 cited in Sukarsono 2005).
Fishers were exempt from this policy and could live $400 \mathrm{~m}$ from the sea, but protests were raised nonetheless. There was little consultation with those displaced by the tsunami who abhorred the top-down policy (ACHR 2006). By March 2005, arguments against the buffer zones by those affected were faltering and community-based consultations were demanded by donors and beneficiaries alike. The blanket policy of buffer zones was lifted, as was evident during a field visit in 2007 that I made to Lok Nga, c. 10 $\mathrm{km}$ west of Banda Aceh, on the hardest hit west coast. There, an entire village had been rebuilt not more than 400 $\mathrm{m}$ from the sea, around a large mosque that had largely survived the tsunami. While many of the Turkish Red Crescent constructed houses were vacant due to poor (seasonal) water supply at the time, they have been considered among the best reconstructed buildings in the wake of the destruction.

In both cases, the buffer zone proclamations initially represented the position of central governments which then evolved and became more geographically tailored and politically-sensitive. In both Aceh and Sri Lanka, criticism in the immediate aftermath of the tsunami also focused on international non-governmental organisations' neglect in consulting with their national and local counterparts in the immediate aftermath of the tsunami (Couldrey \& Morris 2005). As mentioned above, in Aceh the top-down policy was contested early on. In Sri Lanka, although coordination of tsunami aid began in the President's office, it soon became clear that such centralisation of control was not politically popular. Provincial civil servants met with international NGO (INGO) staff until late in most nights in early 2005, in attempts to allocate projects in affected areas to different organisations; to make peace with warring NGOs who claimed similar areas to rebuild, and to avoid duplicating services or aid provision. In Aceh too, INGOs competed with one another for space to conduct their humanitarian projects (Renner 2006).

One major policy distinction between the two contexts in the delivery of post-tsunami aid - at least at the outset - was the more centralised planning in the form of a blueprint by the Government of Indonesia in contrast to the more decentralised planning and coordination that eventually took place at the national, provincial and district levels in Sri Lanka, with international non-governmental organisations taking major roles and staking claims to particular projects and places. The relative influence of these private, if non-profit, international organisations compared to the Sri Lankan governing authorities at various scales remains an important issue that has been addressed by Sunil Bastian (2007b) in his recent book.

The pursuit of private for-profit interests in humanitarian reconstruction must also be addressed. In both Sri Lanka and Aceh, the rationale for the buffer zones was public safety, but as soon as the policy was announced in Aceh, private sector developers and other political insiders began jockeying for a piece of the post-tsunami reconstruction pie outlined in the blueprint (Renner 2006), attempting to profit from what Naomi Klein (2005) has called 'disaster capitalism'. Klein visited Sri Lanka after the tsunami and voiced concern that tsunami funds would be used for 
private contractors to build new port facilities and an inland superhighway which were not necessarily related to the destruction caused by the tsunami.

Researchers need to prove or dispute these ideas before reproducing them further. In Aceh, critics have recently raised concerns about why a new superhighway was built (not rebuilt) along Aceh's sparsely populated west coast after the tsunami. Speculation that the discovery of oil reserves off Aceh's west coast requires such road infrastructure and that international donors may have known about such reserves even before the tsunami occurred have circulated, but again this requires further investigation to prove or disprove its veracity.

Rich cousin, poor cousin: tsunami aid politics and postconflict integration

Just as disaster is never simply 'natural' (Smith 2006), 'reconstruction is never just a physical task' (Renner 2006, 13). In Sri Lanka along the eastern coast, tsunami-affected people were also intensely affected by conflict, especially in terms of geographical displacement. However, in Aceh, those who were intensely affected by conflict largely did not overlap with those devastated by the tsunami (Waizenegger \& Hyndman in press). In Sri Lanka, communities of people displaced from conflict that were not affected by the tsunami have been largely ignored, at least in terms of tsunami aid. One distinction between conflict-affected people in Sri Lanka and Aceh is that the latter group experienced a dramatic loss in terms of livelihoods after the 2005 peace agreement (MoU, 2005) that required rebel fighters to demobilise and provided very limited funds for their reintegration. However, the MoU (2005) does make provision for reintegration in section 3.2.3:

GoI [Government of Indonesia] and the authorities of Aceh will take measures to assist persons who have participated in GAM activities to facilitate their reintegration into the civil society. These measures include economic facilitation to former combatants, pardoned political prisoners and affected civilians. A Reintegration Fund under the administration of the authorities of Aceh will be established.

The MoU continues to state that all former combatants will receive an allocation of farmland, employment, or adequate social security. However, the number of combatants listed in the MoU (3000 military troops) is widely considered to be an undercount (Renner 2006) Hence the funds for reintegration are paltry. While some senior GAM leaders did receive a 'peace dividend' from the 2005 agreement in the form of jobs with the government agency for reconstruction (BRR, or Badan Rehabilitasi dan Rekonstruksi), the benefits were bestowed among a small, elite minority (Waizenegger \& Hyndman in press).

In Aceh, deep-seated resentment has emerged based on the uneven distribution of funds between GAM commanders versus foot soldiers and on the dramatically different levels of aid available to tsunami survivors as compared to demobilised soldiers: 'The tsunami victims were the lucky ones ... At least they got help' (Ida Wati, former GAM rebel, cited in Honorine 2007); 'while almost USD 8 billion is committed to dealing with the aftermath of the tsunami, only USD 200 million is pledged for reintegration efforts' (Hollenbeck 2007).

A great number of GAM are frustrated, including combatants, non-combatants, and prisoners given amnesty:

We also find a lot of dissatisfaction among GAM themselves. Their job is to fight, so now they are unemployed. They face problems feeding their families. There is a reaction to the fancy cars and 'Indonesian' behaviour that high ranking GAM have shown. GAM commanders got reintegration funds, but foot soldiers got nothing. There is a lot of resentment. (interview with a government representative in Banda Aceh, June 2007).

Reintegration is a highly political matter, with the potential for strong politicisation. The inadequacies of reintegration to date are explored in more depth by other authors (Waizenegger \& Hyndman in press), but this pressing and current problem in Aceh distinguishes it from Sri Lanka, where the cessation of hostilities, let alone peace or reintegration, remains elusive.

\section{Without conclusion}

Having briefly traced the unique antecedents to conflict and policy contexts in Aceh and Sri Lanka, this article has illustrated and analysed the broad contours of post-tsunami political geographies. In Aceh, evidence that the tsunami has accelerated and facilitated peace has emerged. In Sri Lanka, the history, terms and dynamics of conflict since the 2004 disaster are very different, but they have clearly intensified the country's prolonged political crisis. Policies ostensibly aimed at improving public safety in the event of another tsunami instead created antagonism. Government buffer zone policies to restrict rebuilding in designated setback areas along the coast proved highly contentious in both environments, but their outcomes were very different. In Sri Lanka, the buffer zones arguably fuelled ethno-national tensions if not outright conflict, whereas protest of this topdown policy by government (and the donor community) was met with a new, more consultative approach to post-tsunami reconstruction.

Likewise, various policy mechanisms, or blueprints, for distributing post-tsunami aid also proved to have significance beyond the mere logistics of reconstruction. In Aceh the peace agreement specified that some government jobs at the reconstruction agency (BRR) would be made available to ex-GAM members as part of a peace dividend. The blueprint created both the BRR agency for reconstruction and the BRA (Badan Reintegrasi Aceh) agency for reintegration, with formal (if contested) mandates and timelines for operation. In Sri Lanka, no joint mechanism was ever agreed upon. The Post-tsunami Operational Management Structure (P-TOMS) MoU was a promising political compromise while it lasted. Representation by Muslims, the LTTE rebels, and the Sri Lankan Government made it both an explosive but potentially radical intervention to enable humanitarian aid to be delivered. The political geographies of post-tsunami Aceh and Sri Lanka are thus, in one sense, a study in contrasts. 
The political landscapes of Aceh and Sri Lanka today are strictly incomparable, yet their common histories of conflict and the tsunami of 2004 warrant further probing. In December 2006, Irwandi Yusuf, a former rebel leader with GAM, won the election for Governor of Aceh Province. Irwandi, who surprised most observers by being elected at all (he won $38 \%$ of the vote), was in jail for treason when the Indian Ocean tsunami crashed on Aceh in 2004. Unlike most of his fellow prisoners, he was able to swim to safety, escaping his cell only after the waves hit. Provincial elections in which newly formed parties will run are to be held in Aceh in 2009. Nonetheless, resentment is brewing among exGAM foot soldiers and those who lost their livelihoods with the cessation of hostilities. Disparities between the conflictaffected and the tsunami-affected also fuel the tension (Waizenegger \& Hyndman in press).

All this is a far cry from Sri Lanka where a ceasefire agreement that had been in place for more than five years was cancelled in 2008, after two members of parliament (one a cabinet minister) were murdered and many more civilians killed in various bomb blasts in public spaces in the first half of the same year (Kleinfeld 2007). Prospects for a ceasefire thus looked increasingly slim, despite the hopes of donors who in 2003 pledged billions of dollars for post-conflict reconstruction. In 2009, a sustained Sri Lankan Government offensive against the LTTE continued. The chances of a ceasefire in this climate are slim to none.

More research needs to be done to ascertain the subtle and contested dynamics of sovereignty and governance at multiple scales in the post-tsunami relief and reconstruction period. The processes and policies employed by international aid organisations, national actors, and those affected by the dual disasters cannot be forced into a strictly comparative framework. The imperial designs and modalities of well-intentioned non-governmental organisations, with headquarters in Europe, Australia, Japan, and North America, may have been begrudgingly accepted by the tsunami-affected countries as the price to be paid for 'humanitarian assistance', but more research analysing these aspects of governance in the wake of so much aid is still needed. Likewise, 'disaster capitalism' (Klein 2005) in Aceh, Sri Lanka, and beyond has yet to be demonstrated. What is clear is that disaster aid has no singular effect on conflict. It may expand the political space to negotiate peace and at the same time breed discontent among those required to give up arms, as in the case of Aceh, or it may catalyse tensions among ethno-national groups in a war of competing nationalisms, as in Sri Lanka - a case of 'both/and'.

\section{Notes}

1 Interviews in Aceh were interpreted with assistance from Arno Waizenegger. The project, funded by the Social Sciences and Humanities Research Council of Canada (SSHRC), aimed to trace the different responses by aid agencies to the tsunami.

2 The entire length of the Sri Lankan coastline was affected. The World Bank estimated that $40 \%$ of damage was along the east coast, $30 \%$ along the southern coast, $20 \%$ in the north (another region seriously affected by conflict), and $10 \%$ along the west coast.

3 I thank Sunil Bastian for his astute observation on this point.
Acknowledgements. - The author would like to thank the Social Sciences and Humanities Research Council of Canada (SSHRC) for funding the research. Thanks are also due to Piers Blaikie for his insights and suggestions for improving this manuscript. Thanks are also due to Ragnhild Lund for the encouragement to write this paper, and to Sunil Bastian, Eva-Lotta Hedman and Mala de Alwis for their comments on earlier drafts. I owe much gratitude to Arno Waizenegger, who was a remarkable research assistant in Aceh in 2007 and 2008.

\section{References}

Abeysekera, C. \& Gunasinghe, N. 1987. Facets of Ethnicity in Sri Lanka. Social Scientists' Association, Colombo.

ACHR (Asian Coalition for Housing Rights). 2006. Tsunami Update. www.achr.net/000ACHRTsunami/Download\%20TS/Tsunami $\% 20$ Update\%20June\%20full\%2006.pdf (accessed December 2008).

Action Aid. 2006. Tsunami Response: A Human Rights Assessment. Johannesburg. www.actionaid.org/docs/tsunami_human_rights.pdf (accessed 19 October 2008).

Aspinall, E. 2007. Guerillas in power. Inside Indonesia. http://insideindone sia.org/content/view/616/47/ (accessed December 2008)

Associated Press. 2005. Sri Lankan President pushes for controversial buffer zone after tsunami scare. 29 March 2005. Associated Press, Colombo.

Bastian, S. 2007a. Globalisation, Foreign Aid and Conflict - The Case of Sri Lanka. International Centre for Ethnic Studies Occasional Paper. International Centre for Ethnic Studies, Colombo.

Bastian, S. 2007b. The Politics of Foreign Aid in Sri Lanka. Colombo, International Centre for Ethnic Studies.

Cassim, N. 2005. Govt. gets flexible on buffer zone rule. Daily Mirror (Sri Lanka) 10 October 2005.

Centre for Policy Alternatives. 2005. Landlessness and Land Rights in PostTsunami Sri Lanka. Commissioned by International Federation of the Red Cross, Colombo.

Couldrey, M. \& Morris, T. 2005. UN assesses tsunami response. Forced Migration Review Special Issue July 2005, 6-9.

de Alwis, K.A. 2005. The 100-metre rule - What's the logic? The Island 25 May 2005.

Dias, S. 2006. Key donors divided over post tsunami work. Daily Mirror (Sri Lanka) 7 February 2006.

Gaillard, J.-C., Clavé, E. \& Kelman, I. 2008. Wave of peace? Tsunami disaster diplomacy in Aceh, Indonesia. Geoforum 39:1, 511-526.

Glassman, J. 2005. Editorial: Tsunamis and other forces of destruction. Environment and Planning D: Society and Space 23:2, 164-170.

Grundy-Warr, C. \& Sidaway, J. 2006. Political geographies of silence and erasure. Political Geography 25:5, 479-481.

Hedman, E.-L. 2005. Introduction. Forced Migration Review Special Issue July 2005, 4-5.

Hollenbeck, L. 2007. ... and Then There Were Elections. Now What? USINDO, Washington, DC.

Honorine, S. 2007. Tsunami's tide of goodwill leaves rebels in the cold. South China Morning Post 10 September 2007.

Hyndman, J. 2007. Fear and conflict in post-tsunami Sri Lanka. Annals of the Association of American Geographers 97:2, 361-372.

Hyndman, J. \& de Alwis, M. 2004. Bodies, shrines, and roads: Violence, (im)mobility, and displacement in Sri Lanka. Gender. Place and Culture 11:4, 535-357.

Institute for Policy Studies. 2005. Sri Lanka: State of the Economy 2005. Institute for Policy Studies, Washington DC.

Jayawardena, K. \& de Alwis, M. 1996. Embodied Violence: Comunalising Women's Sexuality in South Asia. Kali for Women, New Delhi.

Jeganathan, P. 2005. SouthPaw One. Lines 3:4. www.lines-magazine.org/ Art_Feb05/Pradeep.htm (accessed 12 October 2008).

Jeganathan, P. \& Ismail, Q. 1995. Unmaking the Nation: The Politics of Identity and History in Modern Sri Lanka. Social Scientists' Association, Colombo. 
Jeyeraj, D.B.S. 2005. The state that failed its people. The Sunday Leader 6 February 2005, 17.

Kelman, I. \& Gaillard, J.-C. 2007. Disaster diplomacy in Aceh. Humanitarian Exchange: Practice and Policy Notes 37, 37-39.

Kennedy, J., Ashmore, J., Babister, E. \& Kelman, I. 2008. The meaning of 'build back better': Evidence from post-tsunami Aceh and Sri Lanka. Journal of Contingencies and Crisis Management 16:1, 24-36.

Klein, N. 2005. The rise of disaster capitalism. The Nation 2 May 2005.

Kleinfeld, M. 2007. Misreading the post-tsunami political landscape in Sri Lanka: The myth of humanitarian space. Space and Polity 11:2, 169-184.

Korf, B. 2005. Sri Lanka: The tsunami after the tsunami. International Development Planning Review 27:3, i-vii.

Lawson, V. 2005. Natural disaster or space of vulnerability. AAG Newsletter $40: 3,3-4$.

Le Billon, P. \& Waizenegger, A. 2007. Peace in the wake of disaster? Secessionist conflicts and the 2004 Indian Ocean tsunami. Transactions of the Institute of British Geographers 32:3, 411-427.

Marston, R. 2005. Geography and the Indian Ocean tsunami. AAG Newsletter 40:2, 1, 4 .

MoU (Memorandum of Understanding between the Government of the Republic of Indonesia and the Free Aceh Movement). 2005. http:// old.thejakartapost.com/RI_GAM_MOU.pdf (accessed December 2008).

MONLAR \& ANRHR (Movement for National Land \& Agricultural Reform and Alliance for Protection of National Resources and Human Rights). 2005. Tsunami update II. Lines 3. www.linesmagazine.org/ tsunami/MonlarJan22.htm (accessed 12 October 2008).

Nah, A.M. \& Bunnell, T. 2005. Ripples of hope: Acehnese refugees in posttsunami Malaysia. Singapore Journal of Tropical Geography 26:2, 249-256.

Nesiah, V., Nanthikesan, S. \& Kadirgamar, A. 2005. Post-tsunami reconstruction - new challenges, new directions. Lines 3:4. http://www.lines-magazine. org/tsunami/linestsunamivision.htm (accessed 12 October 2008).

Olds, K., Sidaway, J.D. \& Sparke, M. 2005. Editorial: White death. Environment and Planning D: Society and Space 23:4, 475-479.

Perera, A. 2005. The buffer zone fiasco. The Sunday Leader 25 December $2005,16$.

Renner, M. 2006. Unexpected promise: Disaster creates an opening for peace in a conflict-riven land. World Watch 19, 10-16, November/December 2006. http://www.worldwatch.org/node/4663 (accessed 27 February 2008).
Sambandan, V.S. 2005. Tsunami and rehabilitation: The rebuilding phase Frontline: India's National Magazine from the publishers of The Hindu 22:4 12-25 February 2005.

Smith, N. 2006. There is no such thing as 'natural' disaster. Published on 11 June 2006 in the SSRC (Socal Science Research Council) serie 'Understanding Katrina: Perspectives from the Social Sciences'. http:// understandingkatrina.ssrc.org/Smith/ (accessed December 2008).

Sparke, M. 2005. In the Space of Theory: Postfoundational Geographies of the Nation-State. University of Minnesota Press, Minneapolis. http:// understandingkatrina.ssrc.org/Smith/ (accessed 29 February 2008).

Spencer, J. (ed.) 1990. Sri Lanka: History and the Roots of Conflict. Routledge, London and New York.

Stokke, K. 2005. After the tsunami: A missed opportunity for peace in Sri Lanka? NIASnytt No. 2, June, pp. 12-13. Copenhagen.

Sukarsono, A. 2005. Tsunami-hit Indonesia to get buffer zone. Reuters Foundation, posted on Relief Web. www.reliefweb.int/rw/rwb.nsf/ db900SID/DDAD-69DUXH?OpenDocument (accessed 10 February 2008).

The Sunday Times. 2006. Coast conservation buffer zone limits relaxed RADA advertisement in The Sunday Times 5 February 2006, 6.

Tiruchelvam, N. 1996. Sri Lanka's ethnic conflict and preventive action: The role of NGOs. Rotberg, R. (ed.) Vigilance and Vengeance: NGOs Preventing Ethnic Conflict in Divided Societies, 147-164. Brookings Institution, Washington DC.

Uyangoda, J. 2005. Ethnic conflict, the Sri Lankan state and the tsunami. Forced Migration Review 24. www.fmreview.org/pdf/uyangoda.pdf (accessed 12 June 2007).

Waizenegger, A. 2007. Secessionist Conflicts and the 2004 Indian Ocean Tsunami. Canada Asia Commentary Vol. 43. Asia Pacific Foundation of Canada (APFC), Vancouver.

Waizenegger, A. \& Hyndman, J. In press. Two solitudes: Post-tsunami and post-conflict Aceh. Disasters.

Wisner, B., Blaikie, P., Cannon, T. \& Davis, I. 2004. At Risk: Natural Hazards, People's Vulnerability and Disasters. Routledge, London. 